\title{
The Interaction of Variety and Environment in Pigeonpea (Cajanus cajan) Trials
}

\author{
R. Abrams, J. Vélez Fortuño, and J. López Garcia ${ }^{1}$
}

\section{INTRODUCTION}

Pigeonpea is one of the major grain crops cultivated in Puerto Rico. It is commercially cultivated mainly in the South, Southwestern, and Northwestern parts of the Island. The variability of the environment in the Island is a well-known fact to plant breeders; soil types and fertility levels vary considerably throughout the Island, the temperature and rainfall pattern varies greatly from year to year, as well as from one region to another.

Variety tests conducted for the purpose of comparing seed yields and other characters of selected material with standard varieties are of considerable importance in all crop-improvement programs. These tests are usually grown over years and locations; thus, for an efficient varietal evaluation program, it seemed desirable to obtain information on the importance of variety $\mathrm{x}$ environment interactions.

The purpose of this paper is to present estimates of variety $\mathrm{x}$ location, variety $\mathrm{x}$ year, and variety $\mathrm{x}$ location $\mathrm{x}$ year interactions and to consider their implications in selection.

\section{MATERIALS AND METHODS}

For estimating the interaction variances, data for 3 years at 2 locations involving 20 varieties and lines of pigeonpeas were available. The varieties used, Kaki and Saragateado, have been grown commercially in Puerto Rico both for canning and for marketing as a fresh product. The other entries included in each test were 16 radiation-delivered lines from Kaki, one introduction from Trinidad, P. I. 5690, and an all-season variety, Amarillo. Data for the years 1964, 1965, and 1966 were used.

The two test locations were Fortuna and Isabela Substations, in the Southern and the Northwestern Region, respectively. A randomized-block design with three replications was used for all experiments. The plots consisted of two 40-foot rows with 8-foot spacing between rows. The seeds were planted in hills spaced 4 feet apart in the row. Yield, flowering date, weight per 100 seeds, and plant height were recorded for each plot. Sufficient seed for each year's test was produced at the Isabela Substation the year prior to its use.

1 Plant Breeder, Plant Breeder and Head of the Plant Breeding Department, and Assistant Agronomist, respectively, Agricultural Experiment Station, Mayagüez Campus, University of Puerto Rico, Río Piedras, P.R. 
The form of the analysis of variance and the expectation of mean squares are given in table 1. Significance of the various components was determined using the appropriate $\mathbf{F}$ test dictated by the mean-square expectations. The methods for the determination of the variance components are as follows: Variance components:

$$
\begin{array}{ll}
\text { Varieties }\left(\sigma^{2} v\right) & \frac{M_{5}+M_{2}-M_{3}-M_{4}}{r p y} \\
\text { Varieties x locations }\left(\sigma^{2} v p\right) & \frac{M_{4}-M_{2}}{r y} \\
\text { Varieties x years }\left(\sigma^{2} v y\right) & \frac{M_{3}-M_{2}}{r p} \\
\text { Varieties x years x locations }\left(\sigma^{2} r y p\right) & \frac{M_{2}-M_{1}}{r} \\
\text { Error }\left(\sigma^{2} e\right) & M_{1}
\end{array}
$$

TABLE 1.-Form of analysis of variance and mean square expectations

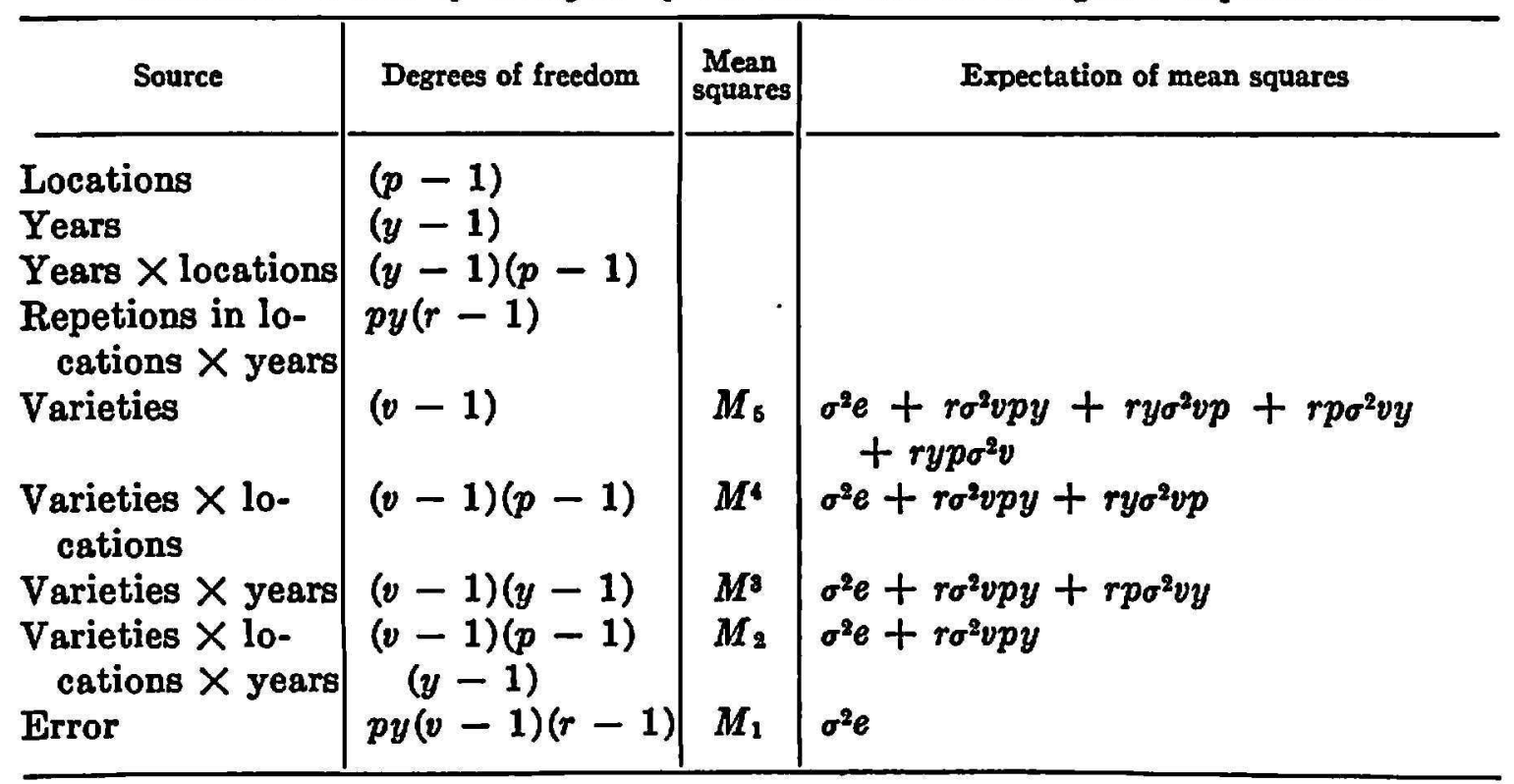

Satterthwaite's $(4)^{2}$ method approximating degrees of freedom was used when two or more mean squares were combined.

\section{RESULTS}

Estimates of the pertinent variance components for yield, flowering date, seed weight, and plant height are presented in table 2. The importance of the components as sources of variation is indicated by their relative magnitude and statistical significance. The variety component was significant at the 1-percent level for all characters studied. Considerable genotypic

2 Italic numbers in parentheses refer to Literature Cited, p. 66. 
variance appears to be present among varieties, as shown by the magnitude of the variety component compared to that of the error component.

The variety $\mathrm{x}$ location source of variation, except for date of flowering, is nonsignificant and negative. Miller et al. (2) have suggested that, since the true parameters cannot be negative, these values must be interpreted as being estimates of variances which are zero or small positive numbers. Such small variety $x$ location interaction tends to indicate that there were no consistent and substantial location effects on differential varietal response in these trials. The 20 varieties yielded similarly to each other at the two locations during the 3 years. Mean yields as averaged over all years for each of the varieties in each of the two locations are presented in table 3 . The reaction of varieties to the environmental conditions during different years in any one location generally were similar to those in the others.

Considering the variety $\mathrm{x}$ year source of variation, except for plant

TABLE 2.-Variance components estimales for combined analysis of pigeonpea variety trials ${ }^{1}$

\begin{tabular}{l|c|c|c|c|c}
\hline \multicolumn{1}{c|}{ Characters } & $\sigma^{20}$ & $\sigma^{2} v y$ & $\sigma^{2 p p}$ & $\sigma^{20 p y}$ & $\sigma^{2} c$ \\
\cline { 2 - 3 } & $51.4^{* *}$ & $8^{*} 9^{*}$ & -1.96 & $10.4^{*}$ & 65.7 \\
Yield & $25.7^{* *}$ & $14.8^{* *}$ & $6.3^{* *}$ & $3.1^{* *}$ & 5.4 \\
Date of flowering & $0.55^{* *}$ & 0 & -.3 & $.27^{* *}$ & .09 \\
Plant height & $3.3^{* *}$ & $.5^{* *}$ & -1.5 & $.6^{* *}$ & 1.0 \\
Seed weight & & &
\end{tabular}

1 * Significant at 5-percent level; ** significant at 1-percent level.

height, it is statistically significant. For plant height and seed weight, the variety $\mathrm{x}$ year interaction component has smaller values than for grain yield and date of flowering. This suggests that number of years should not be decreased when testing for these characters and instead probably increased in order to minimize the magnitude of this interaction.

The second-order interaction of variety $\mathrm{x}$ location $\mathrm{x}$ year is highly significant at the 1 percent level for all characters except yield; however, this source of variation was smaller than the varietal component for all characters. The significance of these tests suggests that some genotype $\mathrm{x}$ environment interaction does occur. The magnitude of the interaction component is relatively smaller than that of the variance among lines, consequently, this interaction component may not be affecting the varietal evaluation very much.

\section{DISCUSSION}

The present data involve varietal experiments with pigeonpeas conducted for the purpose of comparing seed yield, date of flowering, plant height, and 
seed weight of selected radiation-derived lines with standard varieties. In order to evaluate the efficiency of a breeding program, good estimates of genotype $\mathrm{x}$ year and genotype $\mathrm{x}$ location interactions are necessary.

The variety $x$ location component in these studies was small for all characters studied as compared with the variety component. The magnitude of the variety $x$ location component is very small, in fact negative and nonsignificant, except for date of flowering. This significance in date of flower-

TABLE 3.-A comparison of the yield (pounds per plot) of the varieties of pigeonpeas with their relative ranking for $\&$ locations averaged over years

\begin{tabular}{l|r|r|r|r}
\hline \multirow{2}{*}{ Variety } & \multicolumn{2}{|c|}{ Isabela } & \multicolumn{2}{c}{ Ponce } \\
\cline { 2 - 5 } & Yield & Rank & Yield & Rank \\
\hline & Lbs. & & Lbs. & \\
346 & 46.9 & 1 & 64.2 & 1 \\
536 & 40.0 & 2 & 49.9 & 11 \\
344 & 39.9 & 3 & 57.8 & 3 \\
426 & 36.1 & 4 & 49.4 & 12 \\
643 & 35.9 & 5 & 53.2 & 6 \\
166 & 35.1 & 6 & 52.3 & 7 \\
616 & 34.0 & 7 & 55.6 & 4 \\
664 & 33.4 & 8 & 45.3 & 15 \\
425 & 32.0 & 9 & 49.4 & 13 \\
611 & 31.8 & 10 & 50.8 & 10 \\
Kaki & 31.8 & 11 & 61.7 & 2 \\
143 & 31.7 & 12 & 53.8 & 5 \\
456 & 31.6 & 13 & 50.9 & 8 \\
432 & 31.0 & 14 & 47.9 & 14 \\
462 & 29.7 & 15 & 50.9 & 9 \\
Amarillo & 24.6 & 16 & 44.1 & 17 \\
163 & 24.5 & 17 & 44.2 & 16 \\
526 & 18.6 & 18 & 36.9 & 19 \\
P. I. 5690 & 14.9 & 19 & 38.4 & 18 \\
Saragateado & 11.3 & 20 & 34.6 & 20 \\
\hline
\end{tabular}

ing might be attributed more to differences in date of planting at the two locations during the years 1964 and 1965, than to the effect of locations per se. In the present studies the trials have been conducted at only two locations, such a small variety $x$ location component indicates that the 20 varieties behaved similarly relative to each other at the two locations during the years of testing. To substantiate this fact a rank correlation analysis was performed for data in Table 3, and a highly significant correlation of 0.70 between ranks was obtained. This suggests that little would be gained by increasing the number of testing areas or division of the Island into testing areas as proposed by Horner and Frey (1) for oats in Iowa. Never- 
theless, it should be recognized that the data based on two locations may not provide the true picture of variety $\mathrm{x}$ location effects.

The overall magnitude of the variety $\mathrm{x}$ year interaction in the present data was larger than the variety $x$ location interaction, and statistically significant. This indicates that varietal reaction between years was less consistent than between locations. According to this data, it seems advisable to test varieties for more than two years. Optimum number of years for testing the four attributes studied should be determined with further experimentation.

The second order interaction in the present data, although statistically significant for all characters studied, are considerably smaller than the variety component, and equal to or smaller than the variety $X$ year interaction. Since the variety $\times$ location interaction is mostly nonsignificant, this tends to indicate that most of the differential response to environment may be accounted for as year-effect.

Pigeonpea is a well-adapted crop in Puerto Rico. It is grown under a great variety of climatic conditions, different soil types, and is very resistant to drought spells. Investigations by Samuels and Landrau (3) showed that applications of fertilizers to pigeonpea had no effect on yields. The crop is a short-day plant, i.e., flowering is induced during exposures to short-day light. This fact could be a very important factor between locations for the characters studied, but, if we consider that there is a difference of only onehalf degree in latitude $\left(18.0^{\circ} \mathrm{S}-18.5^{\circ} \mathrm{N}\right)$ between the Southern and Northern part of the Island, the relative importance of this factor is minimized and, consequently, the flowering behavior is very similar at both locations.

The results cited in this paper indicate that the data from one location for a period of 3 years or more should be sufficient to eliminate most of the low-yielding entries from a varietal test. The time and expense involved in testing in additional locations may be justified in the final evaluation of the high-yielding lines prior to release, but even in this case two or at most three locations might be sufficient.

\section{SUMMARY}

Twenty varieties of pigeonpeas were evaluated at two locations for a 3-year period. Analysis of these data provided estimates on the nature and magnitude of the variance components for yield, date of flowering, plant height, and seed weight.

The first- and second-order interactions for all characters studied were not as large as the variety component of variance. The variety $\mathrm{x}$ location $\mathrm{x}$ year interaction, although statistically significant, were of small magnitude, and equal to or smaller than the variety $\mathrm{x}$ year interaction. There are clear indications of much greater interaction of varieties $\mathrm{x}$ years in this study, which suggests that the number of years should not be less than three when 
testing for these characters. The variety $\mathrm{x}$ location interaction was of much smaller magnitude than the variety $x$ year interaction, and statistically nonsignificant, except for date of flowering. The significance for date of flowering was explained on the basis of differences in date of planting at the two locations rather than to the effect of locations per se. The experimental data presented in this study reveal the necessity of testing for at least 3 years at one location.

\section{RESUMEN}

Se hizo una evaluación de 20 variedades de gandur en dos localidades durante un periodo de 3 af́os. El análisis estadístico de estos datos proveyó estimados en cuanto a la naturaleza y la magnitud de los componentes de la variación del rendimiento, fecha de la florecida, altura de las plantas y peso de la semilla.

Las interacciones de primer $\mathrm{y}$ segundo orden para los atributos estudiados, fueron menores que la variación del componente atribuido a las variedades. Las interacciones variedades $\mathrm{x}$ años $\mathrm{x}$ localidades, aunque significativas estadisticamente, fueron pequeñas en magnitud e igual o menores que las interacciones de variedades $x$ años. Las indicaciones de este estudio son de que hay una mayor interacción de variedades $\mathrm{x}$ años, lo que sugiere que el número de afios no debe ser menor de 3, al evaluar estos atributos. La interacción de variedad $x$ localidad fue de menor magnitud que la de variedad $x$ año $y$ estadísticamente no significativa, excepto para la fecha de la florecida. Este hecho se explicó a base de diferencias entre las fechas de siembra de los experimentos en las dos localidades y no de diferencias entre las localidades en sí. La evidencia experimental de este estudio sugiere la necesidad de experimentar, por lo menos, durante 3 años en una localidad.

\section{LITERATURE CITED}

1. Horner, T. W. and Frey, K. J., Methods of determining natural areas for oat varietal recommendations, Agron. J. 49: 313-5, 1957.

2. Miller, P. A., Williams, J. C., and Robinson, H. F., Variety $X$ environment interactions in cotton variety tests and their implications on testing methods, Agron. J. 51: 132-4, 1959.

3. Samuels, G., and Landrau, P., The effects of fertilizer applications on yields of pigeonpeas, J. Agri. Univ. P.R. 43 (1): 69-72, 1959.

4. Satterthwaitte, F. E., An approximate distribution of estimates of variance components, Biom. Bull. \&: 110-4, 1956. 